\title{
Comparative Contexts in Legal History: are we all comparatists now?
}

\author{
Contextos Comparativos em História do Direito: somos todos \\ comparatistas agora?
}

\author{
Heikki Pihlajamäki \\ University of Helsinki, Helsinki - Finlândia
}

\begin{abstract}
The article discusses Comparative Legal History from a methodological point of view, seeking to define comparison departing from historiography and demonstrating how the discipline of legal history emerged in the nineteenth century to validate the idea of a national legal science. Secondly, the article presents the traditional idea of comparison as a means of constructing new identities. Finally, it introduces a new method of Comparative Legal History, claiming that the research object can always be located in a wider perspective than the national one. This demonstrates that comparison could be understood as an innate instrument of the legal historian.
\end{abstract}

Keywords: Time. Space. Content. Domestic and Foreign History.
Resumo: O artigo discute a História do Direito Comparada a partir de um ponto de vista metodológico, buscando definir a comparação partindo da historiografia e demonstrando como a disciplina da história do direito emergiu no século XIX para validar a ideia de uma ciência legal nacional. Ademais, o artigo apresenta a ideia tradicional de comparação como um meio para construir novas identidades. Finalmente, introduz um novo método de História do Direito Comparada, reivindicando que o objeto de pesquisa sempre pode ser situado em uma perspectiva mais ampla que a nacional. Isso prova que a comparação pode ser entendida como um instrumento inato do historiador do direito.

Palavras-chave: Tempo. Espaço. Conteúdo. História Interna e Externa.

Recebido em: 26/03/2015

Revisado em: 17/04/2015

Aprovado em: 25/05/2015 


\section{Introduction}

Comparative legal history sounds fashionable, at least in some circles. But what does it mean when we say we write legal history comparatively? It is easiest to take a liberal standpoint and refuse to define the method, approach or whatever we prefer to call it, in any way. The 'let all the flowers bloom' approach is nice and sympathetic: why bother about methodological barriers and definitions, when all we actually want to have is relevant research.

So far, so good. We should not become obsessive about defining disciplinary boundaries now that we have finally managed to start removing them. However, we cannot avoid defining our work methodologically for at least two reasons. For one thing, in order to transgress disciplinary boundaries we had better be aware of just what we are crossing. It is good for a legal historian to possess a command of the sociological, economic or philosophical method, but he or she ought perhaps to be aware when boundaries are crossed. I thus agree with Heirbaut when he says that legal historians ought to stick "to the legal context [leaving] the rest [...] to specialists of other aspects of history, ideally in a team in which the legal historian is a cherished member"'. Heirbaut is correct in highlighting the importance of being aware of one's key competences.

The second reason for which I think defining methods has some significance is a much more mundane one, which has to do with a phenomenon called gate-keeping, which practically all law professors take part in, whether they like it or not. Gate-keeping takes place every time we choose new colleagues for faculties or assess research proposals, for instance. We define not only what is good and not so good, but at times also what 'international private law,' 'labour law' or 'procedural law' is. And yes, the concept of 'comparative legal history' increasingly often begs for a definition as well.

1 Dirk Heirbaut, "Exploring the law in medieval minds," in Anthony Musson and Chantal Stebbings (eds.), Making Legal History: Approaches and Methodologies (Cambridge: Cambridge University Press, 2012), 118-130, 130. 
I have a gate-keeping position of my own as the Articles Editor of Comparative Legal History, which Hart Publishing established in $2013^{2}$. Our "statement of purpose" reads 3 :

\begin{abstract}
Articles will explore both 'internal' legal history (doctrinal and disciplinary developments in the law) and 'external' legal history (legal ideas and institutions in wider contexts). Rooted in the complexity of the various Western legal traditions worldwide, the journal will also investigate other laws and customs from around the globe. Comparisons may be either temporal or geographical and both legal and other law-like normative traditions will be considered. Scholarship on comparative and trans-national historiography, including trans-disciplinary approaches, is particularly welcome.
\end{abstract}

The statement of purpose is precise in defining almost everything acceptable geographically, substantially and temporally: all regions of the globe, both 'internal' and 'external' approaches, all fields of law and all time periods can basically be considered. Comparisons may be temporal or geographical, and can deal not only with law but other normative traditions as well. Rather tolerant, one might conclude. However, in our everyday work as editors of the journal, my colleagues and I, if not constantly, at least every once in a while run into the very heart of the methodological problem: what is a comparison? In this article, I will clarify how I understand the term, and hopefully not only that. My purpose is also no less than to say something of the future of legal history - although necessarily from one limited angle.

I will start with a short historiography of legal history (II), then shift to what I call a traditional understanding of comparative legal history as geographical and temporal comparisons (III). The fourth section will attempt to define my own understanding of comparative legal history in the light of three examples. The last section (IV) will summarize and conclude the article.

2 The first issue came out in May 2013. The journal is the flag-bearer of European Society of Comparative Legal History. The Chief Editor of the Journal is Dr. Seán Donlan.

3 Available in: < http://www.hartjournals.co.uk/clh/index.html>. (read Oct 1, 2013). 


\section{A Short Historiography of Legal History: the discipline as a by- -product of nineteenth-century nationalistic Rechtswissenschaft}

To understand contemporary discussions on comparative legal history - or comparative law, for that matter - it is indispensable to see them against the backdrop of the nineteenth century and the birth of the 'legal science' of Rechtswissenschaft. Historical issues became an integral element of legal studies in the works of Friedrich Carl von Savigny and his followers. What was new in the their works was not only the fact that they integrated history with contemporary law, at least in their programmatic writings, ${ }^{4}$ history being a central avenue to the correct understanding of the law in force. The Historical School also emphasized the importance of the national characteristics of law, in much the same way as other followers of early-nineteenth century Romanticism did with poetry, languages and other cultural phenomena.

The teachings of the Historical School soon started to concentrate their efforts on arranging the normative material 'scientifically,' as a system, while the historical inquiries became increasingly detached from legal dogmatics. Both served the nineteenth-century national legal development in an important, albeit distinct way. National legal dogmatics arranged the normative material inherited as part of the Roman law tradition or pouring out from national legislative bodies and administrative agencies. Legal historians, in turn, provided an important slice of the nationalistic narrative, explaining how history had led national states to the particular situations in law they found themselves in. Because of the legitimizing tendency, much of the legal history became dogmengeschichtlich, explaining legal developments predominantly from the point of view of legislative development.

While positive law and legal scholarship became overwhelmingly nationally oriented in the nineteenth century, counter-movements arose as well. Modern international law is largely a product of the late nine-

4 See Friedrich Carl von Savigny, System des heutigen römischen Rechts I-VIII (Berlin: Veit, 1840-1849). 
teenth and early twentieth centuries, ${ }^{5}$ although it might be artificial to credit national positive law for its inception in any direct way. Perhaps more importantly, comparative law emerged almost simultaneously with the Historical School turning legal scholarship inwards from the age-old ius commune tradition. Starting in the nineteenth century as a response to practical legislative needs, comparative legal scholarship acquired more academic overtones as the century wore on. The Conferences of the Société International de Droit Comparée in Paris (1900) and The Hague (1936) are often seen as turning-points in the history of modern comparative law. ${ }^{6}$

Despite these two clearly cosmopolitan features of the nineteenth and most of the twentieth-century, legal history thus remained steadfastly on national tracks. This holds true for every country. Thus, for instance, classics such as Heinrich Mitteis's Deutsche Rechtsgeschichte (1949), Frederick Pollock and Frederic Maitlands History of English Law before the Time of Edward I I-II (1898) and Adhémar Esmein's Cours élémentaire d'histoire du droit français (1898) all operate in an overwhelmingly national framework.

Interesting deviations from the pattern are the early nineteenth-century attempts at a universal legal history. The most important example of this is Eduard Gans's work on the law of inheritance (Erbrecht in weltgeschichtlicher Entwicklung, 1824). Perhaps universal legal history can best be seen as the last vestige of ius commune type of universal legal thinking rather than modern cosmopolitanism. The all-encompassing approach was doomed to disappear as legal positivism gained ground. ${ }^{7}$

5 On the birth of international law as a modern legal discipline, see Martti Koskenniemi, The Gentle Civilizer of Nations (Cambridge: Cambridge University Press, 2002).

6 See Carlos Petit, "From Paris to the Hague: Edouard Lambert and Droit Commun Législatif," in Claes Peterson (ed.), History and European Private Law: Development of Common Methods and Principles (Stockholm: Institutet för rättshistorisk forskning, 1997), 137-150.

7 I am deliberately excluding Roman law and canon law from the scope of this article. Neither field of study by nature has ever a national focus. 


\section{Comparative Legal History Emerges}

The nationalistic legal histories have served their purpose for as long as national positivism in legal positivist has maintained its position as the dominant paradigm. Cracks in the edifice of the legal positivist paradigm have however been apparent during the last few decades, and this is the case for legal history as well.

New cosmopolitan strands of legal history appeared even before comparative legal history - in the narrow sense of the term. The Argentine historian Ricardo Levene founded probably the first clearly non-national school of legal history in the 1920s. The field that Levene, together with his Spanish colleague Alfonso García-Gallo, defined as their object of study was Derecho indiano, best translated as Spanish colonial law. We should, however, not miss the fact that even though Levene's legal history broke the boundaries of national states, he was inspired by a sort of Latin American nationalism. It was the "common" early modern legal history of Latin America that came to be created through Derecho indiano ${ }^{8}$. The pan-American background of Spanish colonial legal history is indeed interesting when we turn to the next major cosmopolitan school of legal history in the western world, initiated by Francesco Calasso and Helmut Coing in the decades following the Second World War.

Much has been written about Francesco Calasso ${ }^{9}$ and Paul Koschaker, ${ }^{10}$ who were deliberately turning from their national legal history, the Italian and the German respectively, to what came to be known as European legal history. Another major name that ought to be mentioned in this context is Franz Wieacker, whose classic Privatrechtsgeschichte der Neuzeit (1967) made a lasting impact on several generations of legal historians. The work of the founding fathers of European legal history and the success of their paradigm has often been associated with the need of Italian and German scholars to contribute to the rebuilding of

\footnotetext{
8 See Heikki Pihlajamäki, "La invención del derecho indiano: las raíces cosmopolitanas de la disciplina," Revista Chilena de Historia del Derecho 22:1 (2010), 583-592.

9 See Francesco Calasso, Introduzione al diritto commune (Milano: Giuffré, 1951).

10 See Paul Koschaker, Europa und das Römische Recht (München: Beck, 1947).
} 
Europe after the catastrophes that the early nineteenth-century nationalism had brought on Europe. Another important socio-political context for the rise of European legal history was the founding of the European Coal and Steel Community in 1956 as an economic federation first uniting Belgium, England, Germany, France, the Netherlands, and Luxemburg, and then extending in the subsequent decades to more and more countries, thus forming the European Economic Community and then the European Union. As the national legal positivist paradigm no longer dominated completely, giving space to the new European law, so in legal history a demand for wider views also arose. Institutionally, this led to the founding of Max-Planck-Institute for European Legal History in Frankfurt in 1964, with Helmut Coing as its first director.

The paradigms of neither derecho indiano nor European legal history were comparative in the strict sense, replacing the former national framework with larger framework. In Derecho indiano, this was the Spanish colonial law in its many different forms, and in European law it was ius commune, "the common European law." Neither of these approaches ever became dominant. That they would have even intended to completely replace national legal history would have indeed seemed a strange idea to the founding fathers of these schools. Derecho indiano and European legal history were wider platforms from which common features of law could be observed, but they never questioned the need for purely national legal histories.

Both of these schools of legal history have also been criticized, and for similar reasons. The original idea of derecho indiano as a "common law" for all Spanish colonies has long since given way to an understanding of Spanish colonial law as a body of law with many different local variations. The hold of the Spanish lawgiver was never intended to lead to complete uniformity. Local circumstances were taken into consideration from on the outset, and local norm-givers (for instance the audiencias) were also given powers of their own. Furthermore, local variations in customary law developed even when statutory law might have looked the same ${ }^{11}$.

11 On local variation in practice, see Charles R. Cutter, The Legal Culture of Northern New Spain, 1700-1810 (Albuquerque: University of New Mexico Press, 1995). 
European legal history, developed after the works of Calasso, Coing, Koschaker, and Franz Wieacker by such giants of legal history as Manlio Bellomo and Reinhard Zimmermann has also attracted its share of criticism. Douglas Osler published his by now almost classic article on the "myth of European legal history" in 1997. Osler claimed that the standard versions of European legal history had been written from the German point of view, beginning at Bologna and culminating in the glorious Begriffsjurisprudenz of the nineteenth century. In this story, countries such Spain and the Netherlands and even Italy are left with a minor role to play. Italy is certainly the cradle of jurisprudence, but disappears from the story after the middle ages. Spain only appears when the School of Salamanca is discussed, the Netherlands when Elegant Jurisprudence is considered. And so forth ${ }^{12}$.

The omissions of the standard European legal history, repeated in so many textbooks, could be multiplied. The standard story tends to say little about the British Isles, except perhaps in order to contrast continental law with English common law. Scandinavia does not exist and neither does Eastern Europe. It is no wonder that legal historians from these peripheries of Europe generally do not feel at home with textbooks on European legal history textbooks emanating from the pens of their German colleagues. I suspect that my Belgian, Dutch. French, Italian, and Spanish colleagues do not feel completely at ease with most of the textbooks either, which explains the abundance of national legal histories all over Europe.

What is the problem with the traditional, German- and Italian-oriented legal histories? The problem is that in these histories it is always the European heartland that sets the standard. You either follow the standard more or less in time, and you follow the development in the heartlands more or less completely. Thus, the reception of ius commune takes place in Spain "early" and "thoroughly," and in Sweden "late" and "only partially." Little remains to say about Russia, because there is no learned law.

12 D. J. Osler, "The Myth of European Legal History", Rechtshistorisches Journal, 16 (1997), 393-410. 
The standard of European legal history is, in other words, learned law, the ius commune, Roman law and canon law.

Being "standard" means that the legal history of the peripheries is constantly measured against the center. In international conferences and scholarly works, for instance, the question is how the learned law of proof developed in Sweden, to what extent Russian judges received legal education in the nineteenth century, and how notarial functions were handled in early modern England. This is all fine in that it forces us 'peripherals' to look at our legal past with comparative glasses on. We cannot write national legal histories once we put ourselves in contact with the center, but we must tell them how our legal history differs from that of the center and to what extent it is similar to it.

Then what is the problem? Surely the way the influences go makes a difference. Since legal transplants, transfers, or however they are called, seldom travel from the periphery to the center, it might make sense to see how the periphery adopts legal influences. The problem is that we legal historians active in the peripheries perhaps too rarely, when working comparatively, depart from those features that are essential in our histories. The legal historical agenda, or the menu, is set by the center, which can sometimes be irritating to colleagues working outside the core countries. This, however, is a minor problem and not even always the case, hurt feelings aside. A much more serious problem is that the heavily centralized agenda of comparative legal history works, despite what I just said, for the benefit of the periphery - and for its benefit only. The agenda forces the peripheral legal historians to consider how their legal past differs from the center's legal past, but it rarely forces the center to rethink their own legal histories from a larger perspective.

We legal historians are trying to get a grip of our discipline as a global phenomenon, ${ }^{13}$ when in fact a truly European legal history remains to be written. Could comparative legal history solve the problem? I think

13 I have, needless to say, nothing against global legal histories. See, for instance, Thomas Duve, "Von der Europäischen Rechtsgeschichtezu einer Rechtsgeschichte Europasin globalhistorischer Perspektive"; Social Science Research Network, Max Planck Institute for European Legal History Research Paper Series No. 2012-01. 
it could. A truly European legal history would need to be comparative in both the strict and broad sense of the term. I will now try to elaborate the way I see comparative legal history.

\section{Can Comparative Legal History Replace the Nationalistic Pa- radigm?}

I will approach my definition of comparative legal history with the help of three examples. The first one is a comparative study by Richard Ross on early modern legal communication. The second is a hypothesis for a study not realized (at least not yet) on plea bargaining and jury trials. The last example comes from an article I have written on the institution of the notary public.

As mentioned above, comparative legal history in its paradigmatic format follows that of comparative law. To take an example, Richard Ross's excellent article on early modern legal communication compares the way the British and Spanish empires built the communication channels from their respective American colonies to the European metropolises. Ross works systematically, comparing the way the British and the Spaniards employed legal professionals, the extent to which they allowed appeals from the American courts to the appeals instances in London and Madrid, and how each colonial power organized its control over the colonial administration ${ }^{14}$. No doubt this is comparative legal history, and excellent as such.

It may sound obvious, but not every research problem calls for a classic comparative setup. Sometimes, indeed often, we have problems that emanate from more parochial concerns. Take for instance the question of why plea bargaining has gained such tremendous importance in

\footnotetext{
14 See Richard Ross, "Legal Communications and Imperial Governance: British North America and Spanish America Compared," in Christopher L. Tomlins and Michael Grossberg (eds.), Cambridge History of Law in America, Vol. 1, Early America (15801815) (Cambridge University Press, 2008), 104-143.
} 
the United States during the past few decades ${ }^{15}$. If we are interested in solving this legal historical problem, we do not need to solve the corresponding problem in all the countries to which the institution has spread recently. To do so, we need to understand what is so specific about the United States to enable such a curious institution to emerge - and do so well. To find out what is specific about it, we probably would need to place the plea bargaining institution in its procedural context. Plea bargaining cannot be understood in isolation from the trial jury, because it is the jury trial that plea bargaining replaces. Bringing the jury into the discussion would lead one to ask whether the decline of the jury trial is a consequence of the availability of plea bargaining, or whether other reasons could explain the demise of the jury trial. To develop the hypothesis a little further, one would do well to consider the decline of the jury trial in its international context. An international comparison would immediately show that the jury and similar institutions of lay representation (such as the nämnd in Finland and Sweden, or the Schöffen in Germany) have been slowly but surely on the decline in recent decades. The reasons for the decline of the jury in other countries, whatever they might be, would then quite possibly help us to understand why the jury trial has undergone a well-nigh extinction in the United States.

Although the case of plea bargaining and jury trial was made up as an exercise for the purposes of this article only and has not been developed into an actual research project yet, it could well be. I will now take another example of a study that I have actually carried through and in which I utilized a comparative context in a rather similar way. This has to do with the institution of the notarius publicus, the notary public. At the same time, this is an example of a study in legal history emanating from the concerns of the center, as defined above. This, however, is not our main concern now. The notary public is a figure known practically everywhere in continental law, excluding the Nordic countries (Denmark, Finland, Iceland, Norway, and Sweden). The question that naturally arises is why these countries did not adopt the institution of the notary.

15 See for instance, Máximo Langer, "From Legal Transplants to Legal Translations: The Globalization of Plea Bargaining and the Americanization Thesis in Criminal Procedure," Harvard International Law Journal, Vol. 45, No. 1, 2004, 1-64. 
To find the answer, the comparativist needs to know why the institution arose in the jurisdictions where it exists. Notaries existed in ancient Rome. The origins of the modern notary public are in late-Carolingian Italy, where the notary public evolved into an institution responsible for the keeping of public documents (instrumenta publica). Drawing up and attesting the credibility of all kinds of legal documents thus became the main task of the notaries ${ }^{16}$. The figure of the notary public is thus inseparable from a written legal culture that pays increasing attention to written documents. Contracts, wills and other instruments shaping the legal position of the individual were, from the high Middle Ages onwards, increasingly often in writing. Towards the end of the Middle Ages, these instruments also started to enjoy high priority as pieces of evidence - hence the maxim "lettres passent témoins" 17 .

The emergence of the notary public is, furthermore, part and parcel of the rise of the ius commune. The learned bodies of law, Roman and Canon, are connected to the professionalization of law. Notaries came to form one such profession, which spread everywhere where the ius commune did. This is where we find the clue to understanding the Nordic situation and the lack of the notaries in these countries.

The training of legal professionals began late in the Nordic countries: the University of Copenhagen was founded in 1479, and the first Swedish law faculties started functioning only in the seventeenth century. Although training abroad was not uncommon, the legal professionals trained abroad were mainly recruited by the Catholic Church, until the Reformation, and after that by the central governmental institutions of the crown. The judiciary remained very much reliant on laymen for a long time. Local variation exists within the Nordic countries, but in many regions of Finland and Sweden, for instance, lower courts in the coun-

\footnotetext{
16 See, Orazio Condorelli, "Profili del notariato in Italia Meridionale, Sicilia e Sardegna (secolli XII-XIX)," in Mathias Schmoeckel, Werner Schubert (eds.), Handbuch zur Geschichte des Notariats der europäischen Tradition (Baden-Baden: Nomos, 2009), 65-124.

17 See, for instance, the recent article by Mathias Schmoeckel, "Convaincre par l'écrit: La force des documents," in Bernard Durand (ed.), Ars Persuasionis: Entre doute et certitude (Duncker \& Humblot: Berlin, 2012), 165-178.
} 
tryside remained virtually lawyer-free far into the twentieth century. The high courts, the first of which date to the seventeenth century (the High Court of Svea, founded in 1614, being the first one), were staffed partly by noblemen and partly by learned lawyers, although it should be noted that learnedness did not require full doctoral degrees.

Although considerable amounts of learned law percolated through into Swedish legal life, the Rezeption never penetrated as thoroughly as in the European heartlands. Why this was so cannot be treated here in detail. Suffice it to say that the economic resources were long insufficient for a corps of lawyers to emerge and subsist. Since the crown relied largely on the peasant estate as far as running the judiciary was concerned, learned law was not much in demand. The demand for a legal profession, consequently, remained limited as well. It is not difficult to understand that if even advocates were few, no room was left for a separate notarial branch to develop. Furthermore, the lay-dominated legal cultures of Northern Europe were practically oriented, and the use of the written document was certainly less prevalent there than elsewhere. Insofar as written documents were used, much less attention was attached to their accuracy than in the legal cultures in other parts of Europe.

It is now time to extract the essential lessons of the three examples above, attempting to define comparative legal history in some useful way. I would advocate a rather liberal way of defining the comparative approach to legal history. Firstly, comparative legal history can use a systematic method of comparison in much the same way comparative law can. The comparative legal historian can thus (as in the first example drawing on Ross's article) choose a certain number of essential features that the objects of comparison have in common and then analyze their functioning. This is how Ross proceeded in surveying the workings of judicial appeals in the colonial judiciaries of England and Spain, and the organization of legal control mechanisms in the colonies.

But comparative legal history can also be less systematic. The comparative legal historian can take a national or regional legal institution as his concern, exactly as a traditional legal historian working within the boundaries of a national legal system would. However, and this is a 
major difference to the traditional method, the comparative legal historian would always position the research object in an international context. Without this context, the comparative legal historian would feel at risk of losing something essential in trying to answer his or her research questions. The reason why the comparative legal historian would feel this way is that law is an international phenomenon. Not only do legal institutions transfer from one country to another, but the mechanisms through which they change or remain the same are often similar in different countries. Comparative contexts, therefore, can turn out to be true treasure-houses of explanations.

Does this leave any room for purely national legal history? I do not think so, not at least for national legal history, which is completely detached from anything else. Legal history, which orients itself according to the boundaries of national states only, was a product of nineteenthcentury nationalism and national legal positivism. Since that kind of law has become a thing of the past, the legal history that emerged as its byproduct has become equally antiquated. Such legal history tends to stress the specificity of national legal history, even when the features that are considered specific are not so for that particular country at all.

This does not mean, however, that the national state might no longer serve as one possible framework of research. Of course it can, taking into consideration the fact that national states were important law-producing entities long before they became primary motors of legal change. The point of comparative legal history is, however, that one should always be aware of the international context of any legal phenomenon occurring even within a national framework. Sometimes, perhaps, the comparative context will show less in the final research report than in some other cases, but the context should always be there.

Comparative consciousness is not necessary simply because it helps the researcher to test hypotheses and prove or falsify them. A legal historian needs to think comparatively at least as much in order to find out how legal influences, transfer, or translations or transplants move from one legal order to another. Without a consciousness of legal transfers, one is completely at a loss in attempting to explain changes in a particular le- 
gal system. This is not only true for peripheral legal systems but for larger ones as well.

A telling example of the lack of comparative legal history in larger countries is way the history of American legal formalism and realism has traditionally been written. So much has been written about both strands of thought that one might be tempted to doubt whether anything essential could still be missing. And yet there is something missing. None of major contributions to the history of legal formalism have paid attention to the corresponding phenomenon on the European continent, especially Germany. The corresponding phenomenon is, of course, called Begriffsjurisprudenz, conceptual jurisprudence.

Legal formalism and conceptual jurisprudence have so much in common that it is indeed hard to understand why so little comparative work has been written on them ${ }^{18}$. Both schools of thought replaced natural law on their respective home turfs (although in Germany this occurred with the Historical School in between). Both conceptual jurisprudence and legal formalism wished to bring order to what they felt was a messy state of legal sources. For formalists like Christopher Columbus Langdell, this meant reducing the huge number of precedents to a manageable number of cases, and in the Historical School, the predecessor of the Begriffsjurisprudenz, using the historical method to sieve out the most important sources from the jungle of cases, customary law rules, Roman law, and statute law. Both schools brought order to law through ordering their sources into a system. Bringing in the social and political context can at last both be partially explained by the needs of the rising capitalism of the late nineteenth century. Whether these similarities can all be agreed upon is not the point here. Be it this way or that in the detail, these two schools clearly would merit a comparative study, or indeed several.

Exactly the same must be said of American legal realism and its European counterpart, Scandinavian legal realism. Both developed, one could well assume, as responses to the needs of the emerging welfare

18 See, however, David Rabban, "American Responses to German Legal Scholarship: From the Civil War to World War I," Comparative Legal history 1 (2012), 13-43. 
state in the United States on the one hand, and in Sweden and Denmark, on the other. Both schools of legal thought were willing to open legal reasoning to arguments other than purely legal, American legal realists usually emphasizing the importance of the social sciences and Scandinavians the so-called "real arguments" (reella överväganden). As an overwhelming proportion of the realism studies have concentrated on the differences between the different strands of thought within American realism, it is actually not surprising that comparisons with the Scandinavian variant have been rare $^{19}$.

\section{Conclusion}

American legal realism, prevalent in the academic circles of the United States in the interwar period, managed to become so influential that it practically disappeared soon after the Second World War. "We're all realists now," it has often been $\operatorname{said}^{20}$. Should all of us legal historians become comparatists now? Perhaps not in the strict sense of the term, although comparing A and B systematically is a great asset in one's methodological toolbox. But my answer would definitely be yes, if we mean comparative legal history in the broader sense. Legal historians, even if using the national state as their basic unit, should always be able to place their object of research in a broader context, be it European or global.

The need to locate a research unit within a broader context not only concerns a national framework vis-à-vis Europe and the globe, but larger units in relation to others larger units as well. Understanding the specificity of European law requires an understanding of the specificity of other major legal systems, such as Islamic law or Chinese law. A truly modern

\footnotetext{
19 See, however, Gregory Alexander, "Comparing the Two Legal Realisms - American and Scandinavian," American Journal of Comparative Law 2002, 133-143; and Heikki Pihlajamäki, "Against Metaphysics in Law: American and Scandinavian Realism Compared," American Journal of Comparative Law 2004, 469-487. Toni Malminen (University of Helsinki) is currently preparing a dissertation comparing American and Scandinavian realism.

20 The phrase was coined by Gary Peller, "The Metaphysics of American Law," California Law Review 73 (1985), 1151-1290, 1152.
} 
European legal history would, I believe, do just this. A European legal history would, while extracting and defining the particular features of the continent's legal history, also draw not only on the experiences of the center but also those of the various peripheries. Perhaps - just perhaps - our understanding of which regions in different epochs and regarding different subjects and areas of law have been centers and which peripheries might change. A European legal history of the modern kind would then also have a lot to say about the way legal influences have traveled, and still do, from one normative order to another. Perhaps a global legal history could use a similar blueprint?

\section{References}

HEIRBAUT, Dirk. Exploring the law in medieval minds. In: MUSSON, Anthony; STEBBINGS, Chantal (Ed.). Making legal history:

approaches and methodologies. Cambridge: Cambridge University Press, 2012. p. 118-130, 130.

SAVIGNY, Friedrich Carl von. System des heutigen römischen Rechts I-VIII, Berlin: Veit, 1840-1849.

KOSKENNIEMI, Martti. The Gentle Civilizer of Nations. Cambridge: Cambridge University Press, 2002.

PETIT, Carlos. From Paris to the Hague: Edouard Lambert and Droit Commun Législatif. In: PETERSON, Claes (Ed.). History and European Private Law: development of common methods and principles. Stockholm: Institutet för rättshistorisk forskning, 1997. p. 137-150.

PIHLAJAMÄKI, Heikki. La invención del derecho indiano: las raíces cosmopolitanas de la disciplina, Revista Chilena de Historia del Derecho, Chile, v. 22, n. 1, p. 583-592, 2010.

CALASSO, Francesco. Introduzione al diritto commune. Milano: Giuffré, 1951. 
KOSCHAKER, Paul. Europa und das Römische Recht. München: Beck, 1947.

CUTTER, Charles R. The legal culture of Northern New Spain, 17001810. Albuquerque: University of New Mexico Press, 1995.

OSLER, D. J. The Myth of European Legal History. Rechtshistorisches Journal, v. 16, p. 393-410, 1997.

DUVE, Thomas, Von der Europäischen Rechtsgeschichtezu einer Rechtsgeschichte Europasin globalhistorischer Perspektive. Social Science Research Network, Max Planck Institute for European Legal History Research Paper Series, n. 1, 2012.

ROSS, Richard. Legal Communications and Imperial Governance: British North America and Spanish America Compared. In: TOMLINS, Christopher L.; GROSSBERG, Michael (Ed.). Cambridge History of Law in America, Early America (1580-1815), v. 1. Cambridge University Press, p. 104-143, 2008.

LANGER, Máximo. From Legal Transplants to Legal Translations: the Globalization of Plea Bargaining and the Americanization Thesis in Criminal Procedure. Harvard International Law Journal, v. 45, n. 1, p. 1-64, 2004.

CONDORELLI, Orazio. Profili del notariato in Italia Meridionale, Sicilia e Sardegna (secolli XII-XIX). In: SCHMOECKEL, Mathias; SCHUBERT, Werner (Ed.). Handbuch zur Geschichte des Notariats der europäischen Tradition, Baden-Baden: Nomos, 2009. p. 65-124. SCHMOECKEL, Mathias. Convaincre par l'écrit: La force des documents. In: DURAND, Bernard. (Ed.). Ars Persuasionis: entre doute et certitude. Berlin: Duncker \& Humblot, 2012. p. 165-178.

RABBAN, David. American Responses to German Legal Scholarship: From the Civil War to World War I. Comparative Legal history, v. 1, p. 13-43, 2012.

ALEXANDER, Gregory. Comparing the Two Legal Realisms American and Scandinavian. American Journal of Comparative Law, 133-143, 2002. 
PIHLAJAMÄKI, Heikki. Against Metaphysics in Law: American and Scandinavian Realism Compared. American Journal of Comparative Law, p. 469-487, 2004. (Toni Malminen (University of Helsinki) is currently preparing a dissertation comparing American and Scandinavian realism)

PELLER, Gary. The Metaphysics of American Law. California Law Review, USA, v. 73, p. 1.151-1.290, 1.152, 1985.

Heikki Pihlajamäki é professor de História do Direito Comparada da Universidade de Helsinque, Finlândia.

E-mail: Heikki.Pihlajamaki@helsinki.fi

Endereço profissional: Yliopistonkatu 4, 00100 Helsinki, Finlândia. 
